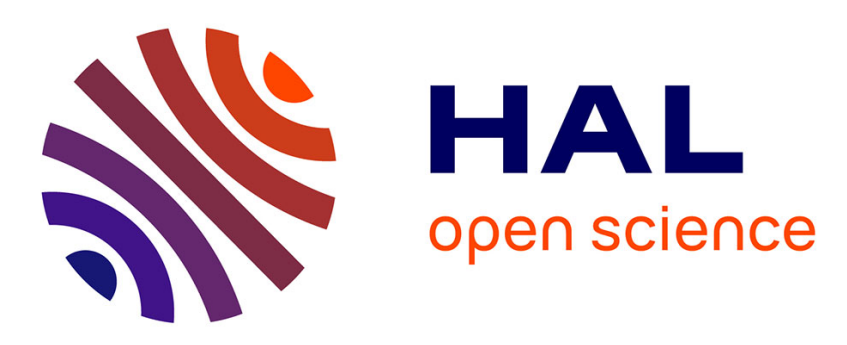

\title{
Solar Resource Assessment for PV Applications
}

Mathieu David, A. Guerin de Montgareuil, J. Merten, D. Mayer, B. Proisy, G.

Olivier

\section{To cite this version:}

Mathieu David, A. Guerin de Montgareuil, J. Merten, D. Mayer, B. Proisy, et al.. Solar Resource Assessment for PV Applications. ISES World Congress 2007, Sep 2007, Beijing, China. Springer Berlin Heidelberg, pp.2588-2592, 2008, 10.1007/978-3-540-75997-3_522 . hal-03193723

\section{HAL Id: hal-03193723 \\ https://hal.univ-reunion.fr/hal-03193723}

Submitted on 9 Apr 2021

HAL is a multi-disciplinary open access archive for the deposit and dissemination of scientific research documents, whether they are published or not. The documents may come from teaching and research institutions in France or abroad, or from public or private research centers.
L'archive ouverte pluridisciplinaire HAL, est destinée au dépôt et à la diffusion de documents scientifiques de niveau recherche, publiés ou non, émanant des établissements d'enseignement et de recherche français ou étrangers, des laboratoires publics ou privés. 


\section{Solar resource assessment for PV applications}

\author{
M. David \\ Laboratory of Buildings and Systems Physics, \\ LPBS, University of La Reunion \\ 40 Avenue de Soweto \\ 97410 Saint-Pierre, France \\ mathieu.david@univ-reunion.fr \\ A. Guerin de Montgareuil \\ CEA / INES - DTS/L2S \\ Cadarache Outdoor Measurement Platform \\ Saint-Paul-lez-Durance, France \\ J. Merten \\ CEA / LITEN-INES/RDI \\ Chambery, France
}

\author{
D. Mayer \\ Armines/CEP \\ Ecole des Mines de Paris \\ Sofia Antipolis, France \\ B. Proisy \\ PHOTOWATT \\ Bourg en Bresse, France \\ G. Olivier \\ TENESOL \\ Toulouse, France
}

\section{$\underline{\text { ABSTRACT }}$}

As many countries, France recently set up an incentive policy for the installation of gridconnected PV-systems. In this context, it becomes important for an investor to be able to calculate the $\mathrm{kWh}$-production from a given system in a specific site. The national program, Performance PV France, gathers research laboratories and French industrials in order to improve the PV system models and the solar resource assessment.

In order to evaluate a better method to monitor the solar resource for PV applications, three sites with different climates were selected. First two ones are located in the metropolitan France, Cadarache and Chambery, and they are respectively representative of the Mediterranean and the Alpine climates. The last one is situated in the Reunion Island coast (south part of Indian Ocean) and it is representative of the insular tropical climate. This monitoring will give a comparison between the solar irradiation measured on inclined planes by pyranometers and PV cells. The second goal of this measurement campaign is the improvement of translation models, from global horizontal irradiation to titled surfaces. In this paper we will present the experimental devices used to evaluate the solar resource with pyranometers and PV cells for 15 planes of different orientations.

\section{INTRODUCTION}

The French government recently decided to promote the development of photovoltaics in France, and especially in the building environment. Feed-in tariffs are now at $0.30 € / \mathrm{kWh}$ for systems non integrated into buildings $(0.40 €$ in Corsica and overseas departments) and $0.55 € / \mathrm{kWh}$ for building integrated systems.

The number of installed systems will probably increase strongly. At this time, there will be a strong competition between all the manufacturers, among them the French module manufacturers PHOTOWATT and TENESOL.

In order to guarantee the success of the development of photovoltaics in France, it is of great importance that all the installed systems will produce what is expected during the expected time. Furthermore, for the French photovoltaic modules industry, it is mandatory to compete with the manufacturers of the rest of the world.

So the objectives of the project Performance PV France are the followings:

- Comparison between the commercial module power peak and the effective power peak,

- Assessment of the solar resources and the climate factors that influence PV productions,

- Life cycle and ageing of PV technologies,

- Buildings integrated PV systems,

- Financial profitability.

The French PV Performance project is dedicated to reach these goals for the products of the French manufacturers and more widely for the systems installed in France.

In order to develop very accurate energy yield prediction methods, one key point is the accuracy of the knowledge of the solar resource. Thus during this paper, we will focus on the accuracy of the measurement and of the prediction of the solar resource in every place and for every module 
orientation. Both terrestrial and satellite measurements will be used inside the global project, initially for the regions with a good solar resource.

Factors influencing system energy yield will be analysed, with a special care on the behaviour of inverters connected to grids in islands. This energy is seldom known with a good accuracy, for several reasons:

- Only the global solar irradiation on a horizontal plane is known

- Measurements are performed with broadband pyranometers, which do not take into account the spectral composition of the light

- Terrestrial meteorological stations are located to far away from the considered place

- Satellite measurements are performed not enough frequently, they are not linked enough accurately to the terrestrial measurements and the scale of the images is too large for small insular territories.

The main objectives of this part of the project are the improvement of the accuracy of the calculation of the available solar energy on a given plane and the measurements of solar spectra in order to link these data to the photo generated current of solar cells.

Three ground base meteorological stations will be set up in three different climates, one at CEA in the platform of Cadarache (Mediterranean climate), one in Chambery in the site of the INES (alpine climate) and one at Saint-Pierre in the site of the LPBS in Reunion Island (inter tropical climate). The stations will perform the standard meteorological measurements, including the measurement of the direct, diffuse and long wave components of the irradiance. They will also perform the measurement of irradiance on fifteen various planes, with global pyranometers and cells from PHOTOWATT and TENESOL. A spectroradiometer will perform frequent measurements of the solar spectrum at Chambery c.

This paper will first present the experimental set up use in the three meteorological platforms to measure the standard solar variables and the global irradiation on fifteen different planes. The second part will expose the expected results.

\section{EXPERIMENTAL SET UP}

We will present more particularly the instrumentation set up in the platform of SaintPierre, Reunion Island (latitude $21^{\circ}$ south, longitude $55^{\circ}$ East). This site is located on the sunniest costal part of the island. The local climate is warm and wet with an average annual temperature close to $24^{\circ} \mathrm{C}$ and an average annual humidity of $70 \%$. Trades winds blow approximately $30 \%$ of time in this part of the island.

The instrumentation is divided in two parts. The first one in a complete weather station (table 2) that measures the standard climate variables with a minute time step [LPBS]. The second part is a semi-hemispheric structure composed by fifteen different planes (figure 1 and table 3). Each plane gathers two PV polycrystalline silicon cells from the two French manufacturers and a secondary standard pyranometers. The table 1 presents the azimuths and the inclinations of the fifteens inclined surfaces. These orientations and inclinations correspond to:

- the ideal inclination of PV fields in Reunion Island : $20^{\circ}$ (latitude of the site),

- the common inclinations of roofs where $\mathrm{PV}$ modules may be installed (between $20^{\circ}$ and $40^{\circ}$ ),

- the best orientations of PV modules for southern territories (from East to West facing North),

- $\quad$ the reference horizontal plane.

The standard part of the weather station gives the same data as the common French weather forecast utilities ground stations. Furthermore, a sun tracker offers additional data concerning the solar radiation as direct normal, diffuse and long wave irradiances. The semi-hemispherical structure permits to concentrate the fifteens planes on a single structure without problems of shading between the different instruments and planes. For each planes, a minute time step monitoring is led on the global solar irradiance, the back face temperature of the PV cells and the short circuit current of these PV cells. The measurement campaign will take place in two steps. In the first one, all the PV cells and the pyranometers will be installed horizontally during a short period (near one week). This phase of calibration will permit to estimate the dispersion of the measurements. It will also permit to detect material failures or incoherency of measurements. The second step, all the PV cells and pyranometers will be mounted on the semi-hemispherical structure. A period of one year of continuous measurements will begin.

The data are all collected on a datalogger with a 10 seconds time step (scan frequency) and they are averaged each minute. So only the minute averages are preserved for the storage. Finally, all the data are stored in a web database. This method of data management permits both the retrieving and the real-time access to the data for the different actors of the project. Such method was already test on our weather station [LPBS]. It offers great possibilities of control of the experimental devices and powerful data treatment. 


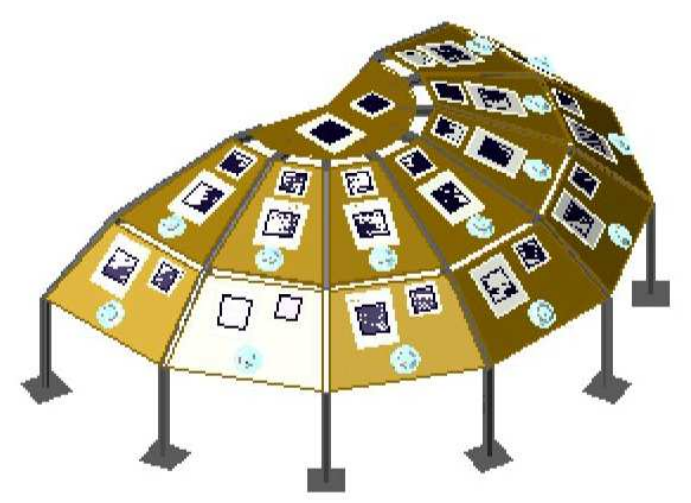

Fig. 1: Semi-hemispherical structure

Table 1: inclinations and orientations of the fifteens planes

\begin{tabular}{|c|c|c|c|c|c|c|c|}
\hline Inclination & \multicolumn{6}{|c|}{ Azimuth } \\
\hline Horizontal & \multicolumn{6}{|c|}{$0^{\circ}$} \\
\hline $20^{\circ}$ & East & $60^{\circ}$ North-East & $30^{\circ}$ North east & North & $30^{\circ}$ North-West & $60^{\circ}$ North-West & West \\
\hline $40^{\circ}$ & East & $60^{\circ}$ North-East & $30^{\circ}$ North east & North & $30^{\circ}$ North-West & $60^{\circ}$ North-West & West \\
\hline
\end{tabular}

Table 2: sensors of the standard weather station

\begin{tabular}{|c|c|c|c|c|}
\hline Support & Sensor & Number & Variables & Unit \\
\hline \multirow{4}{*}{ Sun tracker } & Ventilated pyranometers secondary standard & 1 & Global horizontal irradiation & W.m $\mathrm{m}^{-2}$ \\
\hline & Ventilated pyranometers secondary standard & 1 & Diffuse horizontal irradiation & W.m ${ }^{-2}$ \\
\hline & Pyrgeometer CGR3 & 1 & Long wave irradiation & W.m ${ }^{-2}$ \\
\hline & Normal incidence pyrheliometer & 1 & Direct normal irradiation & W.m ${ }^{-2}$ \\
\hline \multirow{6}{*}{$\begin{array}{l}\text { Weather } \\
\text { tour }\end{array}$} & \multirow{2}{*}{ Thermo-hygrometer HMP45C } & \multirow{2}{*}{1} & Dry bulb temperature & ${ }^{\circ} \mathrm{C}$ \\
\hline & & & Relative humidity & $\%$ \\
\hline & Anemometer A100L & 1 & Wind speed at 2 meters & $\mathrm{m} \cdot \mathrm{s}^{-1}$ \\
\hline & Windvane W200P & 1 & Wind direction at 2 meters & o \\
\hline & Anemometer A100L & 1 & Wind speed at 10 meters & $m \cdot s^{-1}$ \\
\hline & Windvane W200P & 1 & Wind direction at 10 meters & o \\
\hline
\end{tabular}

Table 3: Sensors of the semi-hemispherical structure

\begin{tabular}{|c|l|c|l|l|}
\hline Support & \multicolumn{1}{|c|}{ Sensor } & Number & \multicolumn{1}{c|}{ Variables } & \multicolumn{1}{c|}{ Unit } \\
\hline \multirow{2}{*}{$\begin{array}{c}\text { Semi- } \\
\text { hemisph } \\
\text { erical }\end{array}$} & Ventilated pyranometers secondary standard & 14 & Global irradiation & W.m ${ }^{-2}$ \\
\cline { 2 - 5 } structure & $\begin{array}{l}\text { Polycrystalline silicon PV cells TENESOL }\left(158 \mathrm{~cm}^{2}\right) \\
\text { connected to a precision shunt resistance }\left(5.10^{-3} \Omega\right)\end{array}$ & 15 & $\begin{array}{l}\text { Back temperature of } \\
\text { PV cells }\end{array}$ & ${ }^{\circ} \mathrm{C}$ \\
\cline { 2 - 5 } & $\begin{array}{l}\text { Polycrystalline silicon PV cells PHOTOWATT circuit current }\left(196 \mathrm{~cm}^{2}\right) \\
\text { connected to a precision shunt resistance }\left(5.10^{-3} \Omega\right)\end{array}$ & 15 & A \\
\hline
\end{tabular}

\section{EXPECTED RESULTS}

The first goal of this experimental set up is the evaluation of which meteorological parameters influenced the photo generated current of solar cells under different climates.
Translation models consist to evaluate the total solar energy that yield on inclined surface from the global horizontal solar irradiation. Trigonometric models (2) (3) are usually used to evaluate the total irradiation on inclined planes from global horizontal irradiance because of their easy set up. It is well known that the diffuse part of solar irradiance is directive, and such models assume that 
this diffuse part is isotropic. More complex models (4) (5) (6) (7) (8) use physical description of the passage through the atmosphere of the solar irradiation. This second class of models considers more faithfully the physical phenomena but their set of parameters need to be extremely well estimated to give coherent results. So, in order to improve the accuracy of the evaluation of the total solar irradiation on inclined planes under different climates, this experimental project will offer a useful database. For the comparison and the validation of these models we can notice a restriction on the planes of maximum irradiance used for PV implantations.

Photo generated current of solar cells is considered to be strongly correlated with the level of solar irradiance. In order to improve the quality of the solar resource and the environmental conditions assessment for PV grid connected systems, it is pertinent to lead a comparison between the common solar radiation measurements with pyranometers and calibrated PV cells. The spectral response of pyranometers is constant while the spectral response of PV cells depends on the technology, the cover materials (figure 2) and environmental parameters such air temperature. The results of this comparison could lead to new methods in order to evaluate with accuracy the solar resource and the energy production of PV fields.

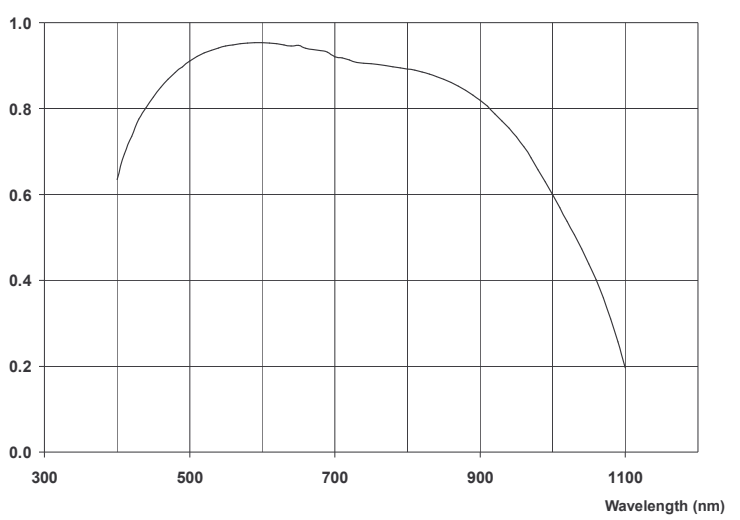

Fig. 2: Spectral response of PHOTOWATT polycristalline cells

\section{4. $\underline{\text { CONCLUSION }}$}

The experimentation presented during this paper is dedicated to feed with data different studies as validation of models or analysis of influences. The developments in these different ways are all related with the same objective of improvement of the method of prediction of the energy production of PV systems in French territories.

\section{REFERENCES}

(1) http://lpbs.univ-reunion.fr/

(2) D.M. Utzinger, S.A. Klein, "A method of estimating monthly average solar radiation on shaded receivers", Solar Energy, vol. 23, pp. 369378, 1979.

(3) J.A. Duffie, W.A. Beckman, "Solar Engineering of Thermal Processes", Second Edition, WileyInterscience Publication, 1991.

(4)M. Iqbal, "An introduction to solar radiation", Toronto, Academic Press, 1983.

(5) Perez, R., R. Stewart, C. Arbogast, R. Seals and J. Scott (1986), "An anisotropic hourly diffuse radiation model for sloping surfaces: Description, performance validation, site dependency evaluation", Solar Energy, Volume 36, Issue 6, p. 481-497.

(6) Gueymard C., "SMARTS2, a simple model of atmospheric radiative transfer of sunshine: algorithms and performance assessment", Document FSEC-PF-270-95 Florida Solar Energy Centre, 1679 Clearlake Road, Cocoa, Florida, 32922-7703, 1995.

(7) F. J. Olmo, J. Vida, I. Foyo, Y. Castro-Diez and L. Alados-Arboledas, "Prediction of global irradiance on inclined surfaces from horizontal global irradiance", Energy, Volume 24, Issue 8, p. 689-704, August 1999.

(8) Danny H. W. Li and Joseph C. Lam, "Predicting solar irradiance on inclined surfaces using sky radiance data", Energy Conversion and Management, Volume 45, Issue 11-12, July 2004. 